\title{
Behavioral Problems in Preschool Children with Orofacial Clefts
}

\author{
Francislaine da Silva ${ }^{1}$ \\ Graduate Program in Psychology of Development and Learning of the "Júlio de Mesquita \\ Filho" State University, Bauru, SP, Brazil \\ Olga Maria Piazentin Rolim Rodrigues \\ Graduate Department in Psychology of Development and Learning of the "Júlio de Mesquita \\ Filho" State University, Bauru, SP, Brazil \\ José Roberto Pereira Lauris \\ Department of Pediatric Dentistry, Orthodontics and Public Health of the University \\ of São Paulo, Bauru, SP, Brazil
}

\begin{abstract}
The present study aimed to evaluate behavioral problems in 83 children with orofacial clefts and to test for possible correlations between these problems and the following variables: gender, age and cleft type. The instruments used were: Interview Protocol and the CBCL. Descriptive analysis of the data was performed using measures of frequency and percentage and the Chi-squared test was used to test for possible correlations. The results showed a higher frequency of externalizing behavior problems in boys. Higher rates of internalizing problems $(62.2 \%)$ and total problems $(46.7 \%)$ were also found in older children. Regarding the relationship between cleft type and behavioral problems, a prevalence of internalizing behaviors was observed, regardless of the type. Considering the behavioral profile that composes the internalizing and externalizing scales, an association between male gender and aggressive behavior was observed; between the 3 years to 4 years 3 months age group and aggressive behavior; and between the pre-incisive foramen cleft and trans-incisive foramen cleft types and internalizing behavior, with emphasis on anxiety/depression problems (50\% and $27.1 \%$ respectively). It is considered that these data can contribute to the planning of preventive and interventional actions, as internalizing and externalizing behaviors reduce the opportunity for adequate interactions and, hence social development.
\end{abstract}

Keywords: Children's behavior, behavior problems, cleft lip and palate.

\section{Problemas Comportamentais em Crianças Pré-Escolares com Fissura Labiopalatina}

\section{Resumo}

O presente estudo objetivou identificar problemas de comportamento de 83 crianças com fissura labiopalatina e testar a correlação entre esses problemas e as variáveis sexo, idade e tipo de fissura. Os instrumentos utilizados foram: Protocolo de Entrevista e o CBCL.Procedeu-se a análise descritiva dos dados utilizando medidas de frequência e porcentagem e,para as associações, foi realizado o Teste

Mailing address: Departamento de Pós-Graduação em Psicologia do Desenvolvimento e Aprendizagem, Av. Eng. Luiz Edmundo Carrijo Coube, 1401, Vargem Limpa, Bauru, SP, Brazil 17033-360. Phone: (14) 31036000.E-mail: franlorca24@yahoo.com.bre olgarolim@fc.unesp.br 
Estatístico do Qui-quadrado. Os resultados mostraram maior frequência de problemas de comportamento externalizantes em meninos. Verificou-se porcentagem maior de problemas internalizantes $(62,2 \%) \mathrm{e}$ problemas totais $(46,7 \%)$ em crianças mais velhas. Quanto à relação entre tipo de fissura e problemas comportamentais pode-se constatar a prevalência de comportamentos internalizantes, independentemente do tipo. Considerando o perfil comportamental que compõem as escalas internalizantes e externalizantes, foi observada uma associação entre sexo e comportamento agressivo, com destaque para os meninos; idade e comportamento agressivo, com destaque para 3 a 4 anos e 3 meses e, tipo de fissura pré-forame e transforame e comportamento internalizante, com destaque para os problemas de ansiedade/depressão (50\% e $27,1 \%$ respectivamente). Considera-se que tais dados podem contribuir para o planejamento de ações preventivas e interventivas, uma vez que comportamentos internalizantes e externalizantes reduzem as oportunidades de interações adequadas e, consequentemente, de desenvolvimento social.

Palavras-chave: Comportamento infantil, problema de comportamento, fissura labiopalatina.

\section{Problemas de Conducta en Niños Preescolares con Fisuralabiopalatina}

\section{Resumen}

Este estúdio objetivó identificar los problemas de comportamiento de 83 niños con fisura de lábio y paladar e probar la correlación entre estos problemas y el género, la edad y el tipo de fisura. Los instrumentos utilizados fueron: Protocolo de Entrevista y el CBCL. Se procedió al análisis descriptivo de los datos utilizando medidas de frecuencia y porcentaje, y para las asociaciones, se realizó la prueba estadística de Chi-cuadrado. Los resultados mostraron una mayor frecuencia de problemas de comportamiento exteriorizado en los niños. Se encontró un mayor porcentaje de problemas de internalización $(62.2 \%)$ y problemas totales $(46.7 \%)$ en niños de más edad. La relación entre el tipo de fisura y problemas de comportamiento puede observar la prevalencia de conductas de internalización, independientemente del tipo. Teniendo en cuenta el perfil de comportamiento presentes en escalas de internalización y externalización, se observó una asociación entre el sexo y el comportamiento agresivo, especialmente para los niños; la edad y el comportamiento agresivo, especialmente para 3 a 4 años y 3 meses y, el tipo de fisura pre-foramen y transforamen y comportamiento de internalización, poniendo de relieve problemas de ansiedad / depresión (50\% y 27.1\%, respectivamente). Se considera que estos datos pueden contribuir al desarrollo de acciones preventivas y de intervención, ya que los comportamientos de internalización y externalización reducen las oportunidades de interacción adecuados y, por tanto, el desarrollo social.

Palabras clave: Comportamiento infantil, los problemas de conducta, fissura de labio y paladar.

Orofacial clefts are congenital malformations that affect the structures of the face and skull during the embryonic and early fetal period, being clinically represented by clefs of the lip, palate or both (Silva \& Souza-Freitas, 2007). The clefs may present varying degrees of severity according to their length and may be unilateral or bilateral, complete or incomplete. The current classification takes the incisive foramen as its reference point, with clefts that involves the lip being called pre-incisive foramen clefts, the clefts of the palate, post-incisive foramen clefts and the clefts that involves both structures, transincisive foramen clefts (Spina, Psillakis, Lapa, $\&$ Ferreira, 1972). Their etiology can be attributed to genetic and environmental factors that can act separately or in combination (Paranaíba et al., 2010).

Orofacial clefts have various consequences, as, in addition to the aesthetic aspects, individuals are susceptible to difficulties related to chewing, swallowing, hearing, breathing, the impairments 
of the dental arch, constant otorhinolaryngological infections, and phonoarticulate disorders (nasalized voice; Paranaíba et al., 2010).

The orofacial cleft also generates emotional and psychosocial consequences (Lemos \& Feniman, 2010; Oliveira, 2014; Pazinato et al., 2011). These problems produce consequences that involve impaired self-esteem, greater dependence on parents, isolation, avoidance of social contact and reduced verbal ability (Domingues, Picolini, Lauris, \& Maximino, 2011; Oliveira, 2014). Given the consequences of the difficulty of effective communication and compromised physical appearance, individuals with orofacial clefts, becomes targets of marked situations, such as social prejudice, discrimination and ridicule, that can compromise their development and social performance (Guimarães, 2010; Maggi \& Scopel, 2011).

During the first years of life, children go through a series of experiences in their family and school environment that may favor the development of interpersonal skills or behavioral problems (Borsa \& Nunes, 2011). The behavioral problems can include excesses or deficits in the behavior that impair not only the individual that presents them, but also the interaction with the surrounding peers and adults (Bolsoni-Silva \& Marturano, 2010; Del Prette \& Del Prette, 2013).

Studies have highlighted a decline in the social skills of children with orofacial clefts, who are characterized by having fewer friends, fewer social contacts and poorer quality of social interactions, as well as presenting internalizing and externalizing behavioral problems (Murray et al., 2010; Snyder \& Pope, 2010). However, children with orofacial clefts do not perceive themselves different from other children until the age of four or five years, especially if they have good family acceptance (Silva, Locks, Carcereri, \& Silva, 2013). When they expand their social environment, this difference is noted and may cause maladjustments in behavior, personality and social performance, including the abandonment of school (Maggi \& Scopel, 2011).

Imperfect appearance can lead to unfavorable social responses as consequences of stig- mas (Silvaet al., 2013). The speech compromise produces distress, due to not being understood, giving the impression of intellectual limitations and physical and social disabilities (Guimarães, 2010; Ha, Zhuge, Zheng Shi, Gong, \& Wang, 2013; Lemos \& Feniman, 2010; Maggi \& Scopel, 2011; Pazinato et al., 2011). In addition to nicknames, children with malformations are regarded with curiosity, prejudice and present difficulties making new social contacts, integrating and adjusting (Miguel, Locks, \& Prado, 2009).

Thus, studies focused on the interpersonal relationships of children with orofacial clefts are important, especially early in their school activities at the time of their entry into preschool. For the child with a facial deformity, this represents the first and most important systematic experience outside the home environment (Graciano, Tavano, \& Bachega, 2007). At this time, the child leaves the safe and protected environment of his family to face an unfamiliar environment, which presents requirements and diverse rules, including interaction with previously unknown people, where the child does not have all the necessary social skills to deal effectively with the school environment (Buffa, 2009).

The school environment encountered by children with orofacial clefts is a new challenge, as they will face new relationships, will be looked at, judged and evaluated on their physical appearance, as well as on their communication, which are important variables in these judgments (Graciano, Tavano, \& Bachega, 2007; Miguel et al., 2009). As a result, this environment provides conditions that can generate behaviors of shyness, withdrawal or aggression, which, when perceived by the child, may influence the socioemotional performance (Guimarães, 2010; Maggi \& Scopel, 2011; Thamilselvan, Kumar, Murthy, Sharma, \& Kumar, 2015).

Considering these findings, Murray et al. (2010) evaluated the social-emotional functioning of school age children with orofacial clefts, through direct observations of social interactions and representations of the child, as well as reports from mothers and teachers. They found that the children had an increased risk for socioemotional difficulties in the school year. The re- 
ports of teachers indicated anxious, introspective and depressed behaviors, and the direct observations revealed difficulties in social interactions, especially communication problems.

Similar data were found in a study by Richman and Millard (1997), which showed increasing levels of social inhibition over age for the girls and a slight consistent increase in internalizing behavior for the boys. It also identified increasing levels of conduct problems for older girls, with variable age fluctuation for the boys.

In a systematic review of the literature on the psychosocial effects in children and adults with orofacial clefts, Hunt, Burden, Hepper and Johnston (2005) found it difficult to classify what psychological and social problems would occur. In the data analysis, they pointed out that, in most cases, children and adults with clefts did not seem to have more psychosocial problems than children without malformations, although some specific problems were observed, such as behavioral problems, dissatisfaction with facial appearance, depression and anxiety. Considering the different types of cleft, few differences were found in relation to self-concept, satisfaction with facial appearance, depression, learning problems and interpersonal relationships. With few exceptions, the age of the subjects with clefts did not appear to influence the occurrence or severity of psychosocial problems related to this condition.

Psychosocial adjustment and social skill problems were investigated by Pope and Snyder (2005), in a sample of 724 children with congenital craniofacial anomalies, aged 2 to 18 years, through the Child Behavior Checklist (CBCL), developed by Achenbach and Rescorla (2001). They found clinical scores for isolation problems in children of 2 to 3 years of age. They identified higher rates of introversion problems, attention deficit and internalizing problems in the 4 to 11 years age group. The boys aged 4 to 11 years presented clinical scores for school and overall competence, while the girls presented more clinical problems in the social problem, attention deficit and social competence scales.

In another study, Snyder and Pope (2010) investigated psychosocial adjustment patterns in children and adolescents aged 2 to 18 years with a diagnosis of orofacial cleft, through the CBCL. The authors found significant scores for social problems and deficits in social and academic skills. They identified clinical scores for externalizing problems and total behavior problems in the children 2 to 3 years of age with trans-incisive foramen clefts. In the children aged 4 to 11 years clinical score for social problems, social competence and total behavior problems were found. The children who had post-incisive foramen clefts, aged 4 to 11 years, presented clinical scores in social problems.

When analyzing the literature, considering children with orofacial clefts aged between 3 and 5 years, a shortage can be found of national and international studies investigating behavioral problems in this population. In this context, the social and empirical relevance of the present study is justified, aiming to contribute to the identification and comprehension of the behavioral profile of children with orofacial clefts. With regard to the theoretical aspects, it would be significant to fill the gap in the literature on the subject.

Based on the literature, this study considered the following hypotheses: (a) the rates of behavioral problems for the sample of this study will be higher than the overall mean of the reference sample of the test; (b) a greater number of behavioral problems will be recorded for children with trans-incisive foramen clefts, considered more severe, than for children with preincisive and post-incisive foramen clefts; (c) for the boys more externalizing behavior problems will be identified and, for the girls, more internalizing behavior problems, and (d) the older children will show an increase in levels of behavioral problems when compared to the younger children.

Considering the above, the present study aimed to identify the behavioral problems of 83 children with orofacial clefts and to test for correlations between these problems and the gender, age and type of cleft variables. While the specific aims were: (a) to identify the behavior problems (internalizing and externalizing) in preschool children with orofacial cleft, as re- 
ported by their mothers; (b) test for possible correlations between the behavioral problems (internalizing and externalizing) and the variables gender, age and type of cleft.

\section{Method}

\section{Participants}

The study included 83 children, 48 boys $(57 \%)$ and 35 girls $(42 \%)$, with orofacial clefts. Of the sample, 38 (45.78\%) were aged between 3 years and 4 years 3 months and $45(54.21 \%)$ between 4 years 4 months and 5 years 10 months. A total of $62(74.70 \%)$ of the children of the sample were attending school. Regarding the type of cleft, 37 (44\%) had trans-incisive foramen clefts, $30(36 \%)$ post-incisive foramen clefts and 16 (19\%) pre-incisive foramen clefts. All were undergoing treatment in the Craniofacial Anomaly Rehabilitation Hospital of the University of São Paulo (HRAC/USP), located in the city of Bauru in the state of São Paulo.

\section{Instruments}

An interview protocol developed by the researcher was used to characterize the sociodemographic conditions, which consisted of open and closed questions, with information regarding the identification of the child and data of the family components. For the identification of indicators of behavioral problems of the children the preschool version (1 $1 / 2$ to 5 years) of the Child Behavior Checklist (CBCL) was used. This instrument consists of 99 items, aimed at the evaluation of behavioral problems of children. From the report of the mothers, the items related to behavioral problems were classified according to a three-point scale: item false or behavior absent (score $=0$ ); item partially true or sometimes present (score $=1$ ) and item very true or behavior often present ( $\mathrm{score}=2$ ). These were recorded and summed in scales, providing the behavioral profile of the child. The behavioral profile is evaluated through seven axes or syndromes (Emotional Reactivity, Anxiety and Depression, Somatic Complaints, Isolation, Sleep Problems, Attention Problems and Aggressive Behavior) and through the scales of Internaliza- tion, Externalization and Total behavioral problems (Achenbach \& Rescorla, 2000). An electronic version of the $\mathrm{CBCL}$, the ADM enables the conversion of the raw scores to $\mathrm{T}$ scores, based on the frequency of the CBCL items in the American population. Cutoffs points in $\mathrm{T}$ scores determine the non-clinical, borderline and clinical categories for the social and behavioral scales (Achenbach \& Rescorla, 2000).

\section{Procedures}

The research project was submitted to the Research Committee and to the Research Ethics Committee of the Craniofacial Anomaly Rehabilitation Hospital of the University of São Paulo - USP/Bauru and received authorization (CEP-CAAE No. 05988512.2.0000.5441). The physical and moral integrity of all mothers and children participating was ensured, covering the ethical aspects considered essential in research with human subjects, according to Resolution 196/96 of the National Health Council (CONEP; Ministério da Saúde, 2012).

For the data collection, a survey was carried out in the Scheduling Center of the Hospital of the patients that only presented orofacial clefts and that would be called for a routine outpatient consultation between September and December 2012. There was an initial prediction of inviting at least 120 mothers. However, of the 92 mothers invited, 83 agreed to participate, (those who did not accept did not have time). At the time of the consultation the meetings for possible participation in the project were scheduled. In the first meeting the mothers were informed about the study, its aims and procedures. Any doubts were explained, their rights and obligations confirmed and they were invited to voluntarily participate. When the mothers accepted they signed the consent form.

Initially, the interview protocol was individually applied, containing a script for collecting the sociodemographic data. This was followed by the application of the Child Behavior Checklist instrument (CBCL, preschool version). The mothers were informed that the questionnaire contained a list of items describing behaviors of children. It was requested that they considered 
their child in the previous two months and mark the items appropriately. The duration of each application was approximately 15 minutes.

For correction of the CBCL, the Assessment Data Manager 7.0 (ADM 7.0) software was used. The ADM 7.0 program, after correcting the answers provided for the CBCL items, classifies the child into the categories 'clinical' (above 70 scores), 'borderline' (scores between 65 to 69 ) and 'non-clinical' (scores lower than 64; Achenbach \& Rescorla, 2000).

\section{Data Analysis}

Data were coded and entered into Excel ${ }^{\circledR}$ spreadsheets, creating a database for analysis using the statistical package Statistica, version 12.0 (Stat Soft Inc., Tulsa, USA).

Initially, a descriptive analysis was performed to characterize the profile of the participants regarding the sociodemographic characteristics (gender and age) and the type of cleft, using measures of frequency and percentage.

The chi-squared test was used to verify the associations between socio-demographic data, type of cleft and the behavioral problems of the children assessed through the CBCL. The Table of $\chi^{2}$ was consulted, considering the critical value for $\alpha$ of 5\% equal to 3.841 and 5.991. The significance criterion of $p<.05$ was adopted in all analyzes.

\section{Results}

According to the reports of the mothers when responding to the CBCL, it was observed that of the 83 children assessed, 47 (56.6\%) had internalizing behavior problems at clinical levels. With respect to externalizing problems, 26 $(31.3 \%)$ of the mothers reported their presence in the behavioral repertoire of their children, also at clinical levels. Considering the total behavioral problems, these were present in $39(47 \%)$ of the children at clinical levels (Table 1).

Regarding the dimensions of the Diagnostic and Statistical Manual of Mental Disorders (DSM), assessed through the CBCL, of the 83 children, 41 (49.4\%) presented clinical indicators of attention deficit and hyperactivity problems,
$40(48.2 \%)$ of anxiety disorders, $33(39.8 \%)$ presented clinical indicators of developmental problems, $30(36.1 \%)$ of emotional problems, and $24(28.9 \%)$ of oppositional defiant problems. Considering the behavioral profile of all of the children evaluated through the seven axes or syndromes that make up the $\mathrm{CBCL}$, it was observed that $23(27.7 \%)$ had clinical indicators of 'anxiety/depression', followed by 18 (21.7\% ) with 'attention problems', 16 (19.3\%) 'emotional reactivity problems', 15 (18\%) had indicators of 'isolation', 14 (16.9\%) of 'aggressive behavior', $13(15.7 \%)$ of 'somatic complaints' and 7 (8.4\%) of 'sleep problems' (Table 1).

Table 2 shows that internalizing behaviors occurred at clinical levels for 27 (56.3\%) of the boys and $21(60 \%)$ of the girls, while externalizing problems occurred in $18(37.5 \%)$ of the boys and $9(25.7 \%)$ of the girls. Total problems were more present in the behavior of the boys (23, $47.9 \%)$ than in the girls $(15,42.9 \%)$.

The children were between 3 years and 5 years 10 months of age. They were divided into two age groups: 3 years to 4 years 3 months ( $n$ $=38)$ and 4 years 4 months onwards $(n=45)$, as shown in Table 2. The group of older children $(28,62.2 \%)$ presented more internalizing behaviors at clinical levels than the group of younger children (20, 52.6\%). The younger children (13, $34.2 \%$ ) presented more externalizing behaviors than the older children $(14,31.1 \%)$ and the older children $(21,46.7 \%)$ presented more total problems than the younger children $(17,44.7 \%)$.

All the children in the sample had foramen clefts, which, for this analysis, were divided into pre-incisive foramen $(n=16)$, post-incisive foramen $(n=30)$ and trans-incisive foramen $(n=$ $37)$ clefts. Of the children, $10(62.5 \%)$ of those with pre-incisive foramen clefts, $21(70 \%)$ of those with post-incisive foramen clefts and 17 (45.9\%) of those with trans-incisive foramen clefts presented internalizing behaviors at clinical levels. Three $(18.7 \%)$ of the children with pre-incisive foramen clefts, nine $(30 \%)$ of those with post-incisive foramen clefts and $15(40.5 \%)$ of the children with trans-incisive foramen clefts presented externalizing behaviors. The children with trans-incisive foramen clefts $(19,51.4 \%)$ 
Table 1

Description of the Indicators of Behavioral Problems Evaluated by the CBCL

\begin{tabular}{|c|c|c|c|c|}
\hline \multirow{2}{*}{$\begin{array}{l}\text { Behavioral } \\
\text { Indicators }\end{array}$} & \multicolumn{4}{|c|}{ Frequency } \\
\hline & \multicolumn{2}{|c|}{ Non-clinical } & \multicolumn{2}{|r|}{ Clinical } \\
\hline Behavioral Problems & $N$ & $\%$ & $n$ & $\%$ \\
\hline Internalizing & 36 & 43.4 & 47 & 56.6 \\
\hline Externalizing & 57 & 68.7 & 26 & 31.3 \\
\hline Total Problems & 44 & 53 & 39 & 47 \\
\hline DSM Dimensions & $N$ & $\%$ & $n$ & $\%$ \\
\hline Affective Problems & 53 & 63.9 & 30 & 36.1 \\
\hline Anxiety Problems & 43 & 51.8 & 40 & 48.2 \\
\hline Development Problems & 50 & 60.2 & 33 & 39.8 \\
\hline Attention Deficit and Hyperactivity Problems & 42 & 50.6 & 41 & 49.4 \\
\hline Oppositional Defiant Problems & 59 & 71.1 & 24 & 28.9 \\
\hline Axes or Syndromes & $N$ & $\%$ & $n$ & $\%$ \\
\hline Emotional Reactivity & 67 & 80.7 & 16 & 19.3 \\
\hline Anxiety/Depression & 60 & 72.3 & 23 & 27.7 \\
\hline Somatic Complaints & 70 & 84.3 & 13 & 15.7 \\
\hline Isolation & 68 & 82 & 15 & 18 \\
\hline Sleep Problems & 76 & 91.6 & 7 & 8.4 \\
\hline Attention Problems & 65 & 78.3 & 18 & 21.7 \\
\hline Aggressive Behavior & 69 & 83.1 & 14 & 16.9 \\
\hline
\end{tabular}

presented more total problems than the children with post-incisive foramen clefts $(13,43.3 \%)$ and those with pre-incisive foramen clefts $(6$, $37.5 \%$; Table 2 ). There was no statistically significant difference in the comparison between groups, considering age, gender and type of cleft of the children.

Data on the dimensions assessed by the CBCL are shown in Table 3, which reveals high frequency of developmental problems in both genders, $16(33.3 \%)$ boys and $11(31.4 \%)$ girls. A total of $12(25 \%)$ of the boys presented clinical indicators for problems of anxiety and $12(25 \%)$ for attention deficit and hyperactivity, while $9(25.7 \%)$ of the girls presented indicators for anxiety and 7 (20\%) for attention deficit and hyperactivity problems. The boys presented risk for emotional problems and oppositional defiant problems, 9 (18.7\%), each, while $4(11.4 \%)$ of the girls (each) presented these problems. However, for the studied sample, there was no association between gender and the dimensions of the DSM assessed by the CBCL.

Considering the age of the children, Table 3 shows that $15(33.3 \%)$ of the older children presented clinical indicators of developmental problems, while $12(31.6 \%)$ of the younger children presented them. Regarding the problems of anxiety and attention deficit and hyperactivity, it was noted that $11(28.9 \%)$ and $10(26.3 \%)$ of the younger children, respectively, presented clinical indicators, while $10(22.2 \%)$ and $9(20 \%)$ of 
Table 2

Associations of Internalizing, Externalizing and Total Behaviors, from the Report of the Mothers, according to Gender, Age and Type of Cleft of the Children

\begin{tabular}{|c|c|c|c|c|c|c|c|c|c|c|c|c|}
\hline \multirow{2}{*}{ Variable } & \multicolumn{4}{|c|}{ Internalizing } & \multicolumn{4}{|c|}{ Externalizing } & \multicolumn{4}{|c|}{ Total Problems } \\
\hline & Non-clin. & Clin. & $\chi^{2}$ & $p$ & Non-clin. & Clin. & $\chi^{2}$ & $p$ & Non-clin. & Clin. & $\chi^{2}$ & $p$ \\
\hline $\begin{array}{l}\text { Male } \\
(n=48)\end{array}$ & $21(43.7)$ & $27(56.3)$ & I & $m$ & $30(62.5)$ & $18(37.5)$ & $\infty$ & $\infty$ & $25(52.1)$ & $23(47.9)$ & $\bar{\nabla}$ & $\infty$ \\
\hline $\begin{array}{c}\text { Female } \\
(n=35)\end{array}$ & $14(40)$ & $21(60)$ & $\dot{0}$ & $\ddot{0}$ & $26(74.3)$ & $9(25.7)$ & - & ก. & $20(57.1)$ & $15(42.9)$ & $\because$ & 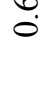 \\
\hline $\begin{array}{c}3 \mathrm{y}-4 \mathrm{y} 3 \mathrm{~m} \\
(n=38)\end{array}$ & $18(47.4)$ & $20(52.6)$ & & & $25(65.8)$ & $13(34.2)$ & & & $21(55.3)$ & $17(44.7)$ & & \\
\hline $\begin{array}{c}4 \mathrm{y} 4 \mathrm{~m} \text { and } \\
\text { over } \\
(n=45)\end{array}$ & $17(37.8)$ & $28(62.2)$ & $\stackrel{\infty}{\circ}$ & $\stackrel{\infty}{\infty}$ & $31(68.9)$ & $14(31.1)$ & : & $\begin{array}{l}t \\
\stackrel{0}{0}\end{array}$ & $24(53.3)$ & $21(46.7)$ & $\stackrel{\overbrace{}}{0}$ & $\begin{array}{l}8 \\
0 \\
\infty \\
0\end{array}$ \\
\hline $\begin{array}{l}\text { Pre-incisive } \\
\text { foramen } \\
(n=16)\end{array}$ & $6(37.5)$ & $10(62.5)$ & & & $13(81.3)$ & $3(18.7)$ & & & $10(62.5)$ & $6(37.5)$ & & \\
\hline $\begin{array}{l}\text { Post-incisive } \\
\text { foramen } \\
(n=30)\end{array}$ & $\begin{array}{c}9 \\
(30)\end{array}$ & $21(70)$ & $\exists$ & $\stackrel{\infty}{\stackrel{\infty}{1}}$ & $21(70)$ & $\begin{array}{c}9 \\
(30)\end{array}$ & $\stackrel{n}{n}$ & $\stackrel{\widehat{\hat{~}}}{\hat{\sigma}}$ & $17(56.7)$ & $13(43.3)$ & $\stackrel{\infty}{o}$ & $\begin{array}{l}\frac{\pi}{\sigma} \\
0 \\
0\end{array}$ \\
\hline $\begin{array}{l}\text { Trans-incisive } \\
\text { foramen } \\
(n=37)\end{array}$ & $20(54.1)$ & $17(45.9)$ & & & $22(59.5)$ & $15(40.5)$ & & & $18(48.6)$ & $19(51.4)$ & & \\
\hline
\end{tabular}

the older children, respectively, presented these indicators. With regard to emotional problems and oppositional defiant problems, $8(17.8 \%)$ and $7(15.6 \%)$ of the older children, respectively, presented indicators, compared to $5(13.2 \%)$ and $3(7.9 \%)$ of the younger children, respectively. The data show that there was, for the population studied, a significant association between age and the dimensions of the DSM assessed by the CBCL.

Table 3 shows that $5(31.2 \%)$ of the children with pre-incisive foramen clefts presented 'anxiety problems' and 5 (31.2\%) 'developmental problems', $11(36.7 \%)$ of the children with post-incisive foramen clefts presented 'developmental problems' and 8 (26.7\%) 'attention deficit and hyperactivity' and of those with transincisive foramen clefts, $11(29.8 \%)$ presented 'developmental problems', $10(27 \%)$ 'anxiety problems' and $10(27 \%)$ 'attention deficit and hyperactivity'. No significant associations were found.

Analyzing the items that make up the developmental problems identified, higher indicators were found for the questions related to: (1) Not responding when addressed by others; (2) Being nervous with new people or situations; (3) Being disturbed by a change in routine; (4) Avoiding looking people in the eye; and (5) Problems in the speech. The information from question 1 suggests that the children of the sample may have presented deficits in sustained auditory attention, as has been previously noted, which makes it impossible for the children to maintain the attentional focus, leading to them not responding when addressed by other people. Questions 2 and 3 may be related to the anxiety of the children facing difficult situations in their 
day-to-day. Whereas the majority of the children in the sample attended preschool and/or needed to undergo outpatient consultations and/or hospitalizations for the treatment of the cleft, it can be inferred that contact with new situations or people and changes in the routine can cause maladjustments of behavior. The contents portrayed in question 4 may be related to the cleft itself, suggesting that these children already perceive themselves as different, or, to the matter of shyness, which makes these children avoid looking people in the eye. Regarding question 5 , it can be inferred that this is related to the functional implications of the orofacial cleft.

Table 3

Association of the Dimensions of the DSM Evaluated by the CBCL according to Gender, Age and Type of Cleft of the Children

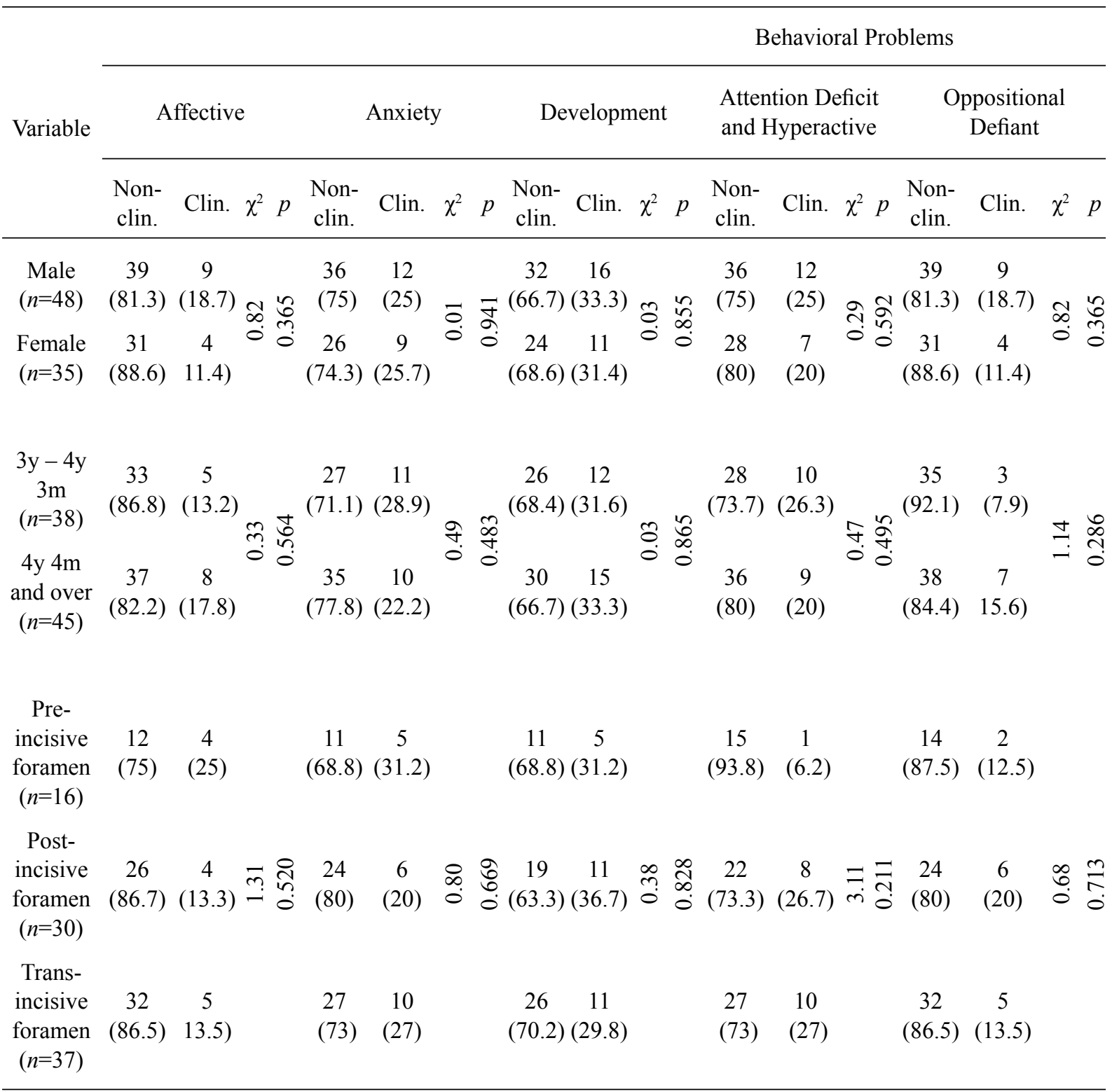

The axes or syndromes assessed by the CBCL were also analyzed. Table 4 shows that 16 $(33.3 \%)$ of the boys presented clinical indicators for 'anxiety/depression' problems and $12(25 \%)$ for 'aggressive behavior'. Regarding the girls, 8
(22.9\%) presented 'emotional reactivity' clinical indicators, $7(20 \%)$ indicators of 'anxiety/ depression' and 7 (20\%) 'attention problems'. The data showed that 'aggressive behavior' ( $p=.020$ ) was more present among the boys, with 


\begin{tabular}{|c|c|c|c|c|c|c|c|}
\hline \multirow{4}{*}{ 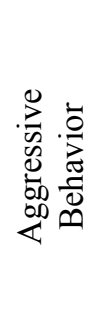 } & 2 & $0 z 0^{\circ} 0$ & \multicolumn{2}{|c|}{$\varsigma \mathcal{E} 0^{\circ} 0$} & \multicolumn{3}{|c|}{$8+8^{\circ} 0$} \\
\hline & $x$ & $\angle \mathcal{E}^{6} S$ & \multicolumn{2}{|c|}{$9 t^{6} t$} & \multicolumn{3}{|c|}{$\varepsilon \mathcal{E}^{6} 0$} \\
\hline & 0 & $\begin{array}{l}\stackrel{\overbrace{}}{\beth} \\
\cong\end{array}$ & 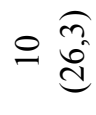 & $\begin{array}{l}\widehat{\sigma} \\
\hat{\infty} \\
\sigma\end{array}$ & $\sim \stackrel{\sqrt[n]{n}}{\mathbb{E}}$ & $\underset{n}{\stackrel{E}{6}}$ & $\sim \widehat{\varrho}$ \\
\hline & Z & 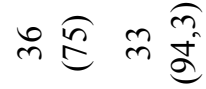 & 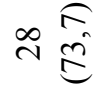 & $F \widehat{\vec{a}}$ & $\pm \frac{\sqrt[n]{n}}{\frac{\infty}{\infty}}$ & $\approx \underset{\infty}{\stackrel{\infty}{d}}$ & 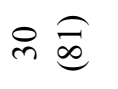 \\
\hline \multirow{4}{*}{ 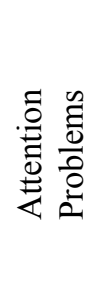 } & 2 & $0 \varsigma L^{\circ} 0$ & \multicolumn{2}{|c|}{$\varsigma 89^{\circ} 0$} & \multicolumn{3}{|c|}{$809^{\circ} 0$} \\
\hline & $x$ & $0 I^{\circ} 0$ & \multicolumn{2}{|c|}{$9 I^{`} 0$} & \multicolumn{3}{|c|}{$66^{6} 0$} \\
\hline & $U$ & 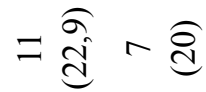 & $a \stackrel{\text { हn }}{\ddot{d}}$ & $a \stackrel{d}{d}$ & 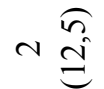 & $-\stackrel{\tilde{m}}{\tilde{d}}$ & $a \stackrel{\text { }}{\stackrel{d}{d}}$ \\
\hline & Z & 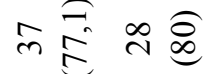 & จे ?ु? & 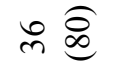 & $\pm \frac{n}{\infty}$ & $\approx \stackrel{\varepsilon}{\varepsilon}$ & $\stackrel{i}{E}$ \\
\hline \multirow{5}{*}{$\frac{0}{0}$} & 2 & $9 t t^{\circ} 0$ & \multicolumn{2}{|c|}{$S \mathcal{S I} I^{6} 0$} & \multicolumn{3}{|c|}{$\mathrm{I} 6 L^{\prime} 0$} \\
\hline & $\pi$ & $8 \mathcal{S}^{6} 0$ & \multicolumn{2}{|c|}{$\varepsilon 0^{\prime} \tau$} & \multicolumn{3}{|c|}{$\angle t^{6} 0$} \\
\hline & $U$ & 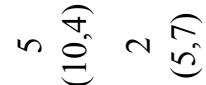 & $n \underset{\widetilde{v}}{\approx}$ & $\sim \underset{f}{\stackrel{f}{ \pm}}$ & $\sim \stackrel{\sqrt[n]{n}}{\Xi}$ & 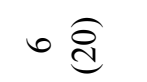 & $m \stackrel{\widehat{\infty}}{\widehat{\infty}}$ \\
\hline & Z & $\stackrel{\sigma}{\sigma} m \stackrel{m}{a}$ & $m \stackrel{\infty}{\infty}$ & $\begin{array}{l}\sigma \\
q \\
\sim\end{array}$ & $\pm \sqrt{n}$ & $\underset{\sim}{\sim} \widehat{\infty}$ & $\dot{m} \vec{\sigma}$ \\
\hline & 2 & IS8 $8^{\circ} 0$ & \multicolumn{2}{|c|}{$619^{\circ} 0$} & \multicolumn{3}{|c|}{$\angle 08^{`} 0$} \\
\hline \multirow{3}{*}{ 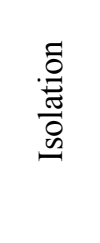 } & $x$ & t06 0 & \multicolumn{2}{|c|}{$\varsigma Z^{6} 0$} & \multicolumn{3}{|c|}{$\varepsilon t^{6} 0$} \\
\hline & $U$ & $a \stackrel{\infty}{\stackrel{\infty}{=}} \cdot \stackrel{\overparen{\Xi}}{\stackrel{\Xi}{=}}$ & $0 \stackrel{\substack{\infty \\
ٌ}}{=}$ & $a \stackrel{d}{d}$ & $\sim \stackrel{\sqrt[n]{n}}{\Xi}$ & $0 \stackrel{\mathrm{d}}{\mathrm{d}}$ & $-\widehat{\varrho}$ \\
\hline & Z & 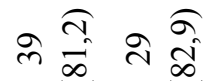 & 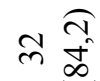 & i $\underset{i}{\stackrel{\infty}{\infty}}$ & $\pm \frac{\sqrt[n]{n}}{\infty}$ & $\stackrel{\sim}{\stackrel{\&}{\&}}$ & $\stackrel{i}{\widehat{\infty}}$ \\
\hline \multirow{5}{*}{ 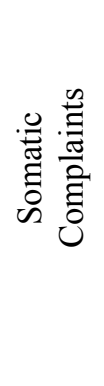 } & 2 & IS L'0 0 & \multicolumn{2}{|c|}{ t9 $9 \varsigma^{\prime} 0$} & \multicolumn{3}{|c|}{$8+\varsigma^{\prime} 0$} \\
\hline & $\pi$ & $0 I^{‘} 0$ & \multicolumn{2}{|c|}{$\varepsilon \varepsilon^{6} 0$} & \multicolumn{3}{|c|}{$0 Z^{6} \mathrm{I}$} \\
\hline & U & 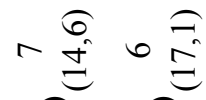 & $n \stackrel{\overparen{\approx}}{\mathscr{g}}$ & $\infty \stackrel{\infty}{\stackrel{\infty}{\Xi}}$ & $m \stackrel{\overparen{\sigma}}{\stackrel{\delta}{=}}$ & 0 वृ & $+\stackrel{\widehat{\sigma}}{\varrho}$ \\
\hline & Z & 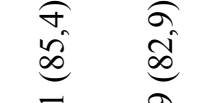 & $\begin{array}{l}\infty \\
\infty \\
\infty \\
\infty\end{array}$ & 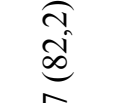 & 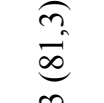 & $\stackrel{\sim}{\mathscr{B}}$ & m $\widehat{\overrightarrow{0}}$ \\
\hline & 2 & $08 I^{\circ} 0$ & \multicolumn{2}{|c|}{$\angle I 8^{6} 0$} & \multicolumn{3}{|c|}{$\varsigma \varsigma 0^{\circ} 0$} \\
\hline \multirow{4}{*}{ 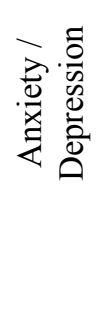 } & $x$ & $08^{6} \mathrm{I}$ & \multicolumn{2}{|c|}{$\varsigma 0^{6} 0$} & \multicolumn{3}{|c|}{$08^{\text {‘ }} \subseteq$} \\
\hline & U & 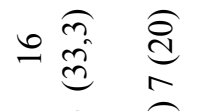 & $=\stackrel{\widehat{\sigma}}{\stackrel{\infty}{d}}$ & $\therefore \underset{d}{\stackrel{E}{d}}$ & $\infty$ 尽 & $n \stackrel{\overparen{E}}{\stackrel{\sigma}{\sigma}}$ & $\circ \underset{\vec{d}}{\widehat{d}}$ \\
\hline & z & $\approx \begin{array}{cc}\hat{E} & \widehat{\theta} \\
\hat{\theta} & \infty \\
0\end{array}$ & $\hat{\imath} \bar{E}$ & $m \stackrel{\approx}{n}$ & $\infty \stackrel{\widehat{n}}{0}$ & $\approx \underset{\sim}{\stackrel{2}{\infty}}$ & $\widehat{\hat{v}} \hat{\underline{s}}$ \\
\hline & 2 & $08 t^{\circ} 0$ & & & & $\varepsilon I Z^{\prime} 0$ & \\
\hline \multirow{3}{*}{ 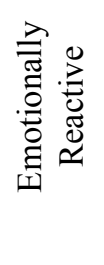 } & $x$ & $0 \varsigma^{\prime} 0$ & & & & $60^{\circ} \mathcal{E}$ & \\
\hline & $U$ & 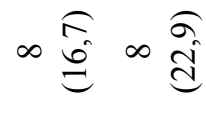 & $\circ$ శ్ & $0 \stackrel{\text { }}{\stackrel{g}{g}}$ & $+\sqrt[\overparen{d}]{2}$ & $\infty \underset{\tilde{d}}{\tilde{d}}$ & $+\stackrel{\widehat{\sigma}}{\varrho}$ \\
\hline & $z$ & 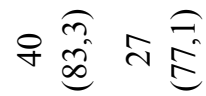 & $\stackrel{\infty}{\sim} \stackrel{\varepsilon}{\varepsilon}$ & के & $\simeq \cong$ & $\approx \stackrel{\approx}{\stackrel{E}{\Xi}}$ & 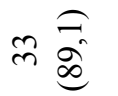 \\
\hline 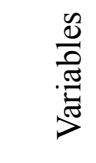 & & 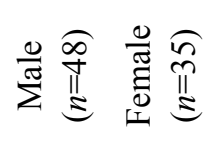 & $\begin{array}{l}\text { Pे } \\
\text { I } \\
\text { I }\end{array}$ & 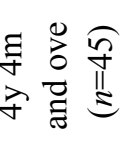 & 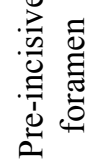 & 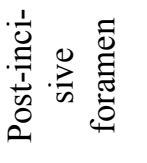 & 竞 \\
\hline
\end{tabular}


statistical significance. Table 4 also shows that $11(28.9 \%)$ of the younger children presented clinical indicators for problems of 'anxiety and depression', 10 (26.3\%) 'emotional reactivity' indicators and $10(26.3 \%)$ 'aggressive behavior. Of the older children, $12(26.7 \%)$ presented clinical indicators for 'anxiety/depression', 9 (20\%) indicators for 'isolation' and 9 (20\%) 'attention problems'. The data demonstrated that 'aggressive behavior' $(p=.035)$ was significantly more frequent among the younger children.

Regarding the types of cleft, Table 4 shows that $8(50 \%)$ of the children with pre-incisive foramen clefts presented clinical indicators for problems of 'anxiety/depression', while 4 (25\%) presented 'emotional reactivity' indicators. Of the children with the post-incisive foramen clefts, $8(26.7 \%)$ presented 'emotional reactivity' clinical indicators, while 7 (23.3\%) of them presented problems of 'attention'. Of the children with trans-incisive foramen clefts, $10(27.1 \%)$ presented clinical indicators for 'anxiety/depression' and 9 (24.3\%) for 'attention problems'. However, there were no significant associations between the type of cleft and the syndromes assessed by the CBCL.

\section{Discussion}

Considering the aim of this study, which was to identify from reports of the mothers, internalizing and externalizing behavior problems in children with orofacial clefts, aged between 3 and 5 years, the prevalence of internalizing behaviors can be seen in the sample. This finding is supported by the study by Murray et al. (2010), which found increased risk for socioemotional difficulties in children with orofacial clefts, with indicators of anxious, introspective and depressed behaviors, as well as difficulties in social interactions, typical of internalizing behaviors. Another study that confirms the results found is that of Pope and Snyder (2005), in which clinical scores for isolation problems were observed in children with craniofacial anomalies in the 2 to 3 years age group and internalizing problems, such as attention and thought problems and introversion, in the 4 years age group.
Regarding the dimensions of the DSM evaluated by the instrument, it was identified that $49.4 \%$ of the sample presented clinical indicators for attention deficit and hyperactivity problems, followed by clinical indications of anxiety problems (48.2\%). Brand and Brennan (2009) and Wehby et al. (2012) also found high risks for attention deficit and hyperactivity problems in school age children with orofacial clefts. With regard to anxiety disorders, the data corroborate the findings of Murray et al. (2010), who identified clinical indicators for anxiety in preschool children with orofacial clefts.

Considering the behavioral profile of the children with orofacial clefts assessed by the seven axes or syndromes that compose the CBCL instrument, there was major clinical indications for anxiety/depression (27.7\%), followed by attention problems $(21.7 \%)$. These data corroborate the findings of Ha et al. (2013), Hunt et al. (2005), Murray et al. (2010), and Pope and Snyder (2005), who identified clinical indications of anxiety/depression and attention problems in preschool children with orofacial clefts.

Regarding the associations of the overall results of the CBCL (internalizing, externalizing and total problems) with the gender variable, it was evidenced that both the boys and girls presented internalizing problems, as was found by Richman and Millard (1997). Nevertheless, a higher percentage of externalizing problems and total behavioral problems were observed in the boys. Overall, these data are consistent with the literature, which shows higher frequencies of externalizing behaviors among boys and internalizing behaviors among girls, also independent of the type of cleft (Blatt-Eisengart et al., 2009; Loosli \& Loureiro, 2010; Nopoulos et al., 2010).

The data also revealed that there were no differences in the frequencies of behavioral problems among older children (4 years and 4 months onwards) and younger children (3 years to 4 years 3 months), unlike that found in the study of Lins, Alvarenga, Paixão, Almeida and Costa (2012), which indicated a higher prevalence of externalizing problems in children of 4 years of age. Similarly, Pope and Snyder (2005) 
found high rates of internalizing problems in children aged 4 years with congenital anomalies. However, the reduced size of the sample analyzed in the present study should be considered.

With regard to the associations of the overall results of the CBCL (internalizing, externalizing and total problems) with the type of cleft, it was found that $70 \%$ of the children with postincisive foramen clefts presented internalizing behavior problems, while $40.5 \%$ of the children with trans-incisive foramen clefts presented externalizing behavior problems and $51.4 \%$ total problems. The results are partially consistent with the findings of Snyder and Pope (2010), who identified clinical scores for externalizing problems and total problems in children 2 to 3 years of age with orofacial clefts. Considering that changes in the palate structures, characteristic of two types of cleft (post- and trans-incisive foramen), may entail specific speech disorders, such as hypernasality and articulation changes resulting from nasal air escape during speech production, it can be inferred that the lack of intelligibility in the communication can lead to psychosocial maladjustment of the child, such as behavioral inhibition, shyness and anxiety, due to not being understood, typical of internalizing behaviors (Lemos \& Feniman, 2010; Pazinato et al., 2011). In addition to speech impairment, there is the facial features characteristic of the trans-incisive foramen cleft, which can also lead to maladjustment of behavior, such as externalizing problems, since the child with a facial defect is looked at, judged and evaluated on their physical appearance (Graciano, Tavano \& Bachega, 2007; Guimarães, 2010; Maggi \& Scopel, 2011).

The results of this study revealed no significant correlations between the dimensions of DSM assessed by the CBCL, the sociodemographic variables of the child (gender and age) and the type of cleft. However, regardless of gender, age and type of cleft, around $30 \%$ of the children, according to the reports of the mothers, presented developmental problems when compared to the other dimensions evaluated. The data obtained indicate the need for further investigation of these problems in this population in future studies.
This study also investigated possible relationships between the seven axes or syndromes assessed by the CBCL and the gender of the children. A significant association was only observed between aggressive behavior and the male gender. This data does not seem to differ in children without health problems, as shown by the literature (Emerich et al., 2012; Loosli \& Loureiro, 2010). However, the results are partially consistent with the findings of Borsa and Nunes (2011), who showed that both boys and girls have a high prevalence of aggressive behavior (externalizing) problems, followed by isolation (internalizing) problems. The authors found no statistically significant difference between boys and girls regarding the different types of behavior problems.

A significant association between aggressive behavior and the age of children with orofacial cleft was also observed, especially for those between 3 years and 4 years 3 months. This data also seems not to differ in children without malformations. This statement is supported by the study of Lins et al. (2012), which highlights externalizing behaviors, such as aggression, as the most common in preschool children, with a tendency to decrease with advancing age, possibly being considered transient in normal development.

Regarding the association between the seven axes or syndromes assessed by the CBCL and the type of cleft of the children, no significant data were found. However, the children with pre-incisive foramen clefts and trans-incisive foramen clefts showed higher percentages of anxiety/depression problems. This data is consistent with the findings of Hunt et al. (2005), who evidenced some specific behavioral problems in children with orofacial cleft, such as anxiety and depression, however, found no significant differences regarding the types of cleft. However, some studies have found that children with orofacial clefts may present a higher degree of anxiety according to the degree of facial deformity, speech difficulties and social relationships (Ha et al., 2013; Masnari et al., 2013). 


\section{Final Considerations}

Regarding the relationship between gender and behavioral problems, the hypothesis was initially confirmed for both genders, where the girls presented a higher frequency of internalizing problems and slight consistent increase in internalizing behaviors and the boys presented a higher incidence of externalizing behaviors. Considering the behavioral profile that composes the internalizing and externalizing scales, an association between gender and aggressive behavior was observed with regard to the boys, corroborating the hypothesis that the boys would be found to present more externalizing behavior problems, however, the results did not corroborate the hypothesis of an association between the girls and internalizing behavior.

The hypothesis that the children with orofacial clefts considered more serious, of the transincisive foramen type, would be found to present more behavioral problems than the children with pre-incisive and post-incisive foramen clefts was not confirmed, since the results showed higher percentages of behavioral problems in the children with the post-incisive foramen type cleft, followed by the children with trans-incisive foramen clefts. However, regardless of the type of cleft, the prevalence of internalizing behaviors was observed in the sample. Considering the behavioral profile that composes the internalizing and externalizing scales, the children with preincisive foramen clefts and trans-incisive foramen clefts showed higher percentages for anxiety/depression problems, partially confirming the hypothesis proposed in this study.

The data did not confirm the hypothesis that the older children would present an increase in levels of behavioral problems, compared to the younger children. It was noted in the study that the older children presented a higher percentage of internalizing problems and total problems, when compared to the younger children, who presented a higher percentage of externalizing problems. However, when considering the behavioral profile that composes the internalizing and externalizing scales, an association between age and aggressive behavior was observed with regards to the three to four years three months age group, not corroborating the hypothesis proposed in the study. The results of this study highlight the need to design and implement preventive and interventional actions aimed at reducing behavioral problems (internalizing and externalizing) in the pre-school context for the population of children with orofacial clefts. Among these strategies the implementation of intervention programs in schools could be suggested, aiming to develop a wide repertoire of social skills, and programs for parents, aiming to promote educational activities about social skills, to act in promoting the social skills of their children, providing them with a more satisfactory way of dealing with the demands of their environment. Considering that the population studied was attended by a multidisciplinary team at the HRAC, such aspects could also be the target of intervention programs of the institution, both in the form of guidance for the parents, as well as actions aimed at the children themselves.

It is necessary, when analyzing the findings of this study, to highlight some limitations of the methodological aspects used. The first refers to the fact that the information related to the behavior of the child was evaluated by the report from a single source, the mother, not including other reporting sources, such as teachers, fathers and caregivers, who could have been questioned. Considering also that some children spend more time with their teachers, caregivers or other family member than with their parents, especially the mother, it could be inferred that another adult would have better knowledge about the behavioral functioning of the child. Another limitation refers to the instrument used that, though widely recognized, does not allow the realization of functional analysis, which could help in the comprehension of the relationship between the type of cleft and internalizing and externalizing problems. The data collection could have been supplemented by instruments that enable such analysis. There is also a lack of national and international studies on the population studied. The majority of the studies about behavioral indicators focus on school age children in the typical development process without orofacial 
disorders, thus limiting comparisons. Therefore, it is strongly recommended that more studies be conducted considering these points.

\section{References}

Achenbach, T. M., \& Rescorla, L. A. (2000). Manual for ASEBA preschool forms \& profiles. Burlington, VT: University of Vermont.

Blatt-Eisengart, I., Drabick, D. A., Monahan, K. C., \& Steinberg, L. (2009). Sex differences in the longitudinal relations among family risk factors and childhood externalizing symptoms. Developmental Psychology, 45(2), 491-502. doi:10.1037/a0014942

Bolsoni-Silva, A. T., \& Marturano, E. M. (2010). Relacionamento conjugal, problemas de comportamento e habilidades sociais de pré-escolares. Psicologia: Teoria e Pesquisa, 26(1), 67-75. Retrieved from http://www.scielo.br/pdf/ptp/ v26n1/a09v26n1.pdf

Borsa, J. C., \& Nunes, M. L. T. (2011). Prevalência de problemas de comportamento em uma amostra de crianças em idade escolar da cidade de Porto Alegre. Aletheia, 34, 32-46. Retrieved from http://www.redalyc.org/ pdf/1150/115022577004.pdf

Brand, S. R., \& Brennan, P. A. (2009). Impact of antenatal and postpartum maternal mental illness: How are the children? Clinical Obstetrics and Gynecology, 52(3), 441-455. doi:10.1097/ GRF.0b013e3181b52930

Buffa, M. J. M. B. (2009). A inclusão da criança com fissura labiopalatina no ensino regular: Uma visão do professor de classe comum (Doctoral dissertation, Hospital de Reabilitação de Anomalias Craniofaciais, Universidade de São Paulo, Bauru, SP, Brazil).

Del Prette, Z. A. P., \& Del Prette, A. (2013). Psicologia das habilidades sociais na infância: Teoria e prática. Petrópolis, RJ: Vozes.

Domingues, A. B. C., Picolini, M. M., Lauris, J. R. P., \& Maximino, L. P. (2011). Desempenho escolar de alunos com fissura labiopalatina no julgamento de seus professores. Revista da Sociedade Brasileira de Fonoaudiologia, 16(3), 310-316. doi:10.1590/S1516-80342011000300012

Emerich, D. R., Rocha, M. M., Silvares, E. F. M., \& Gonçalves, J. P. (2012). Diferenças quanto ao gênero entre escolares brasileiros avaliados pelo inventário de comportamentos para crianças e adolescentes (CBCL/6-18). Psico, 43(3), 380-387. Retrieved from http://revistaseletronicas.pucrs.br/ojs/index.php/revistapsico/article/ view/10053

Graciano, M. I. G., Tavano, L. D'. A., \& Bachega, M. I. (2007). Aspectos psicossociais na reabilitação. In I. E. K. Trindade \& O. G. Silva Filho, Fissuras labiopalatinas: Uma abordagem interdisciplinar (pp. 311-333). São Paulo, SP: Santos.

Guimarães, A. C. P. C. (2010). Jovens com fissura labiopalatina: Avaliação de saúde mental (Doctoral dissertation, Hospital de Reabilitação de Anomalias Craniofaciais, Universidade de São Paulo, Bauru, SP, Brazil).

Ha, P., Zhuge, X., Zheng, Q., Shi, B., Gong, C., \& Wang, Y. (2013). Behavioral pattern in Chinese school-aged children with cleft lip and palate. Asian Pacific Journal of Tropical Medicine, 6(2), 162-166. doi:10.1016/S1995-7645(13)60016-4

Hunt, O., Burden, D., Hepper, P., \& Johnston, C. (2005). The psychosocial effects of cleft lip and palate: A systematic review. European Journal of Orthodontics, 27(3), 274-285. doi:10.1093/ ejo/cji004

Lins, T., Alvarenga, P., Paixão, C., Almeida, E., \& Costa, H. (2012). Problemas externalizantes e agressividade infantil: Uma revisão de estudos brasileiros. Arquivos Brasileiros de Psicologia, 4(3), 57-75. Retrieved from http://pepsic. bvsalud.org/pdf/arbp/v64n3/v64n3a05.pdf

Loosli, L., \& Loureiro, S. R. (2010). Associação entre depressão materna e diferenças de gênero no comportamento de crianças: Uma revisão sistemática. Revista de Psiquiatria do Rio Grande do Sul, 32(3), 94-101. doi:10.1590/ S0101-81082010005000001

Maggi, A., \& Scopel, J. B. (2011). Atendimento aos portadores de fissuras labiais e/ou palatais: Características de um serviço. Aletheia, 34(1), 175186. Retrieved from http://www.redalyc.org/ pdf/1150/115022577014.pdf

Masnari, O., Shiestl, C., Rössler, J., Gütlein, S. K., Neuhaus, K., Weibel, L. Meuli, M., \& Landolt, M. A. (2013). Stigmatization predicts psychological adjustment and quality of life in children and adolescents with a facial difference. Journal of Pediatric Psychology, 38(2), 162-72. doi:10.1093/jpepsy/jss106. 
Miguel, L. C. M., Locks, A., \& Prado, M. L. (2009). $\mathrm{O}$ relato das mães quando do início escolar de seus filhos portadores da má-formação labiopalatal. Revista Sul-Brasileira de Odontologia, 6(2), 155-161. Retrieved from http://www.redalyc.org/articulo.oa?id=153013734007

Ministério da Saúde. (2012). Resolução $n^{\circ} 466$, de 12 de dezembro de 2012. Retrieved from http://conselho.saude.gov.br/resolucoes/2012/Reso466. pdf

Murray, L., Arteche, A., Bingley, C., Hentges, F., Bishop, D. H., Goodacre, T., \& Hill, J. (2010). The effect of cleft on sócio-emotional functioning in school-aged children. Journal of Child Psychology and Psychiatry and Allied Disciplines, 51(1), 94-103. doi:10.1111/j.14697610.2009.02186.x

Nopoulos, P., Boes, A. D., Jabines, A., Conrad, A. L., Canady, J., Richman, L., \& Dawson J.D. (2010). Hyperactivity, impulsivity, and inattention in boys with cleft lip and palate: Relationship to ventromedial pré-frontal cortex morphology. Journal of Neurodevelopmental Disorders, 2(4), 235-242. doi:10.1007/s11689-010-9060-5

Oliveira, R. M. R. (2014). Uma abordagem sobre as dificuldades enfrentadas por mães na amamentação de crianças portadoras de fissuras labiopalatinas. Revista Brasileira de Educação e Saúde REBES, 4(2), 1-6. Retrieved from http://www. gvaa.com.br/revista/index.php/REBES/article/ view/3017

Paranaíba, L. M. R., Miranda, R. T., Martelli, D. R. B., Bonan, P. R. F., Almeida, H., Orsi Júnior, J. M., \& Martelli, H., Jr. (2010). Cleft lip and palate: Series of unusual clinical cases. Brazilian Journal of Otorhinolaryngology, 76(5), 649653. doi:10.1590/S1808-86942010000500019

Pazinato, L. V., Bonow, M. P., Moraes, R. F. P., Liebl, S., Suetugo, R., Pereira, P. P. A., ...Maluf, E. M. C. P. (2011). Qualidade de vida de crianças e adolescentes portadoras de fissura labiopalatal na visão dos cuidadores. Revista da Sociedade Brasileira de Cirurgia Craniomaxilofacial, 14(4), 194-197. Retrieved from http://www. abccmf.org.br/cmf/Revi/2011/out-dez/05Qualidade $\% 20 \mathrm{de} \% 20$ vida $\% 20$ de $\% 20$ crian $\% \mathrm{C} 3 \% \mathrm{~A} 7 \mathrm{as} \% 20 \mathrm{e} \% 20$ adolescentes $\% 20$ portadoras
Pope, A. W. \& Snyder, H. T. (2005). Psychosocial adjustment in children and adolescents with a craniofacial anomaly: Age and sex patterns. Cleft Palate-Craniofacial Journal, 42(4), 349354. doi:10.1597/04-043R.1

Richman, L. C., \& Millard, T. (1997). Brief report: Cleft lip and palate: Longitudinal behavior and relationships of cleft conditions to behavior and achievement. Journal of Pediatric Psychology, 22(4), 487-494. doi:10.1093/jpepsy/22.4.487

Silva, O. G., Filho, \& Souza Freitas, J. A. (2007). Caracterização morfológica e origem embriológica. In I. E. K. Trindade \& O. G. Silva-Filho, Fissuras labiopalatinas: Uma abordagem interdisciplinar (pp. 17-49). São Paulo, SP: Santos.

Silva, C. M., Locks, A., Carcereri, D. L., \& Silva, D. G. V. (2013). A escola na promoção da saúde de crianças com fissura labiopalatal. Texto \& Contexto-Enfermagem, 22(4), 1041-1048. doi:10.1590/S0104-07072013000400021

Spina, V., Psillakis, J. M., Lapa, F. S., \& Ferreira, M. C. (1972). Classificação das fissuras lábiopalatais: Sugestão de modificação. Revista do Hospital das Clínicas, 27(1), 5-6.

Snyder, H., \& Pope, A. W. (2010). Psychosocial adjustment in children and adolescents with a craniofacial anomaly: diagnosis-specific patterns. Cleft Palate-Craniofacial Journal, 47(3), 264-272. doi:10.5555/08-227.1

Thamilselvan, P., Kumar, S. M., Murthy, J., Sharma, M. K., \& Kumar, R. N. (2015). Psychosocial issues of parents of children with cleft lip and palate in relation to their behavioral problems. Cleft Palate-Craniofacial Journal, 2(1), 53-57. doi:10.4103/0971-9261.55152

Wehby, G., Tyler, M. C., Lindgren, S., Romitti, P., Robbins, J., \& Damiano, P. (2012). Oral clefts and behavioral health of young children. Oral Diseases, 18(1), 74-84. doi:10.1111/j.16010825.2011.01847.x
Recebido: 29/07/2015

$1^{a}$ revisão: 11/03/2016

$2^{a}$ revisão: $30 / 04 / 2016$ Aceite final: $31 / 05 / 2016$ 